\title{
Looking for options at the end of the day
}

Previously published at www.cmaj.ca

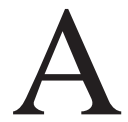
s I write these words I am approaching my 69th birthday. When I was young I entertained the comforting supposition that I might never die. Of course, I knew the syllogism 'All humans are mortal, I am human, therefore...', but I thought that surely an exception could be made in my case. Now that I am increasingly feeling the effects of aging, I know that there will be no exception. Consequently, I think about death - death in general, and mine in particular.

I was born just in advance of the postwar baby boom, but like the boomers I have become accustomed to making the larger decisions for my own life: where to live, what career to pursue, whom to marry, whether to have children, and so on. It seems natural to me to want to be the one in charge of my dying as well, whenever that occurs.

How do I want to go? Peacefully, in my sleep, never realizing that it happened? Fighting to the very end and railing against the injustice of it all? The truth is I don't know, but I do know that I want to be the one who decides. It is to be my way, up to me, executive functioning to the end. But if I am to choose among my own various end-of-life scenarios, I need to know what my options will be. Some of them are in place already. If I manage to remain compos mentis then I will be able to decide how aggressively to resist whatever disease is threatening to carry me off, how much pain medication I need to keep the suffering below my threshold of toleration, and whether nothing in the end will suffice but sedation to unconsciousness. If I want to hasten the end then I can do so by refusing food and water.

But suppose I want more control than this over my dying. Suppose I want to choose the time to go and to have my doctor speed me on my journey with a little medication specifically administered for that purpose? That option is not currently available in many countries, including Canada. Will it be by the time that I might want to avail myself of it? Should it be?

tion. The end was swift, painless and peaceful. None of us will ever forget that moment, especially the two teenage boys. It seemed to me the very paradigm of a good death.

Countless other families have made the same end-of-life decision for their beloved animals. There are a few jurisdictions in the world where people can choose this option for themselves. But not in Canada. For a while, back in the 1990s, there was a good deal of public debate in this country about assisted death, stimulated by two high-profile legal cases: Sue Rodriguez, who sought an assisted suicide, and Robert Latimer, who killed his severely disabled twelveyear-old daughter Tracy. But since that time the issue has pretty much disappeared from the public agenda.

The policy issues are complex and divisive, which is

I have had much occasion to reflect on that last question over the past year or so, during the process of writing a book on assisted death. But nothing has brought it home to me quite so vividly as an incident last fall when one of our beloved cats suffered an unexpected kidney failure. Suddenly as a family we were forced into some end-of-life decision-making. The vet made it clear that there was no way to restore renal function and that we therefore had three choices. Palliative medication was capable of extending the cat's life for two or three weeks at most, but death would then be inevitable. Leaving him untreated would mean that he would die in a day or two. The third alternative was euthanasia, with the entire family present.

We chose what seemed to us the most humane option. We were afforded the opportunity to say our final goodbyes and to hold the animal while the vet administered the injec- exactly why we need an informed public debate about them. Should euthanasia or assisted suicide ever be legalized, I have no idea whether I would want it myself. But I do want to know what my options will be when the time comes. With luck I will have another 20 years or so before these become pressing matters for me. Let's hope that it doesn't take that long to sort it all out.

Wayne Sumner PhD

Professor Emeritus

University of Toronto

Toronto, Ont.

Professor Sumner's new book, Assisted Death: A Study in Ethics and Law, is due to be released in 2010 (Oxford University Press).

Have you got an opinion about this article? Post your views at cmaj.ca. Potential Salon contributors are invited to send a query to salon@cmaj.ca. 